for these proceedings appear in machine-readable databases which make the information available to millions of library users. Proper access to these proceedings makes them more valuable to the scientific, academic, and business communities. With the help of those who prepare and publish conference proceedings library users will be able to locate and use those proceedings more efficiently.
Members of the Ad Hoc Committee that prepared these guidelines are: Dorothy McGarry (chair), University of California, Los Angeles; Grace Agnew, Georgia State University; Carol Cubberley, University of Central Florida; Edward D. Garten, Tennessee Tech University; Sara Shatford, University of California, Los Angeles.

\title{
ACRL list of materials available
}

\section{A complete checklist of ACRL publications in print.}

\begin{abstract}
$\mathrm{S}_{\mathrm{i}}$ Def standards and guidelines are free. Other publications are priced as listed. To ensure that your order is properly processed, include ISBN, author, title, list price, and applicable discount for each item ordered.

Both institutions and individuals may order on account, plus postage and handling; however, prepayment should accompany individuals' orders of $\$ 15.00$ or less. No postage or handling charges are added to prepaid orders (check, money order, credit card). All prices are payable in U.S. funds. The first price stated is list price.
\end{abstract}

ISBN prefix: 0-8389-.

\section{Discounts}

ALA personal and organizational members are eligible to receive a ten percent (10\%) discount on ACRL materials (except subscription items). To receive the discount, give your membership number, and deduct the discount when preparing your orders.

ACRL personal and organizational members receive an additional 20-30\% discount on ACRL materials. Look for the ACRL member prices on this list.

Quantity discounts are available when five or more copies of the same title are ordered to be shipped to the same address. Inquire for prices on specific titles.

\section{Handling charges}

Invoice amounts of $\$ 20.00$ or less, $\$ 1$.

Invoice amounts of $\$ 20.01-\$ 50.00, \$ 2$.

Invoice amounts of $\$ 50.01-\$ 100.00, \$ 3$.

Invoice amounts of $\$ 100.01-\$ 200.00, \$ 4$.

Invoice amounts greater than $\$ 200.00, \$ 5$.

Send orders to: ALA Order Dept., 50 E. Huron Street, Chicago, IL 60611-2795. Free ACRL publications may be ordered from ACRL/ALA at the same address.

\section{ACRL standing order plan}

This plan guarantees that you will automatically be sent all new ACRL publications costing less than $\$ 30$. For details, contact Mary Ellen Davis at the ACRL Office, (312) 944-6780.

\section{Bibliographic instruction}

-Back to the Books: Bibliographic Instruction and the Theory of Information Sources (1983). Papers presented at the Bibliographic Instruction Section program at the 1982 ALA Annual Conference. Edited by Ross Atkinson. 76p. 6587-3. \$15; ACRL members $\$ 12$.

- Bibliographic Competencies for Education Students (1981). Prepared by the Education and Behavioral Sciences Section's Bibliographic Instruction for Educators Committee. Provides ex- 
amples of a wide range of bibliographic sources, and presents a basic rationale for the use of the given examples. Also appears in C $b R L$ News, July/August 1981, in non-tabular form. 2p. Free.

- The Bibliographic Instruction Clearinghouse: A Practical Guide (1984). A guide to establishing a clearinghouse. 71p. 6775-2. \$12; ACRL members $\$ 9$.

- Bibliographic Instruction Handbook (1979). Prepared by the ACRL Bibliographic Instruction Task Force (1971-77) and the Policy and Planning Committee of the ACRL Bibliographic Instruction Section (1977-79). 68p. 6729-9. \$10; ACRL members $\$ 7$.

- Evaluating Bibliographic Instruction: A Handbook (1983). Prepared by the ACRL Bibliographic Instruction Section's Subcommittee on Evaluation. 122p. 6608-X. \$17; ACRL members $\$ 13$.

- Guidelines for Bibliographic Instruction in Academic Libraries (1977). Reprinted from C $b R L$ News, April 1977. 1p. Free.

- Library Instruction Clearinghouses 1985: A Directory. By Joan Ariel. 6960-7. \$6; ACRL members $\$ 5$.

- Organizing and Managing a Library Instruction Program (1979). Prepared by the ACRL Bibliographic Instruction Section's Continuing Education Committee. 30p. 6731-0. \$4; ACRL members $\$ 3$.

\section{Collection development}

- Building a Children's Literature Collection (1983). 3rd ed. Choice Bibliograpical Essay Series, no. 7. \$9.95. 48p. 0-914492-06-3. Order from: Choice, 100 Riverview Center, Middletown, CT 06457.

- Books for College Libraries (2nd ed., 1975). 0178-6. 6 vols., \$80. Single vols., $\$ 15$ each. Vol. 1 , Humanities; Vol. 2, Language and Literature; Vol. 3, History; Vol. 4, Social Sciences; Vol. 5, Psychology, Science, Technology, and Bibliography; Vol. 6, Author, Title, and Subject Indexes. Order from: ALA Publishing, 50 East Huron Street, Chicago, IL 60611. Available on tape from: Inforonics, 550 Newtown Road, Littleton, MA 01460

- Collection Development Policies: CLIP Note \#2-81 (1981). 131p. 6738-8. \$12; ACRL members $\$ 9$.

- Curriculum Materials Center Collection Development Policy (1984) 27p. 6777-9. \$7; ACRL members $\$ 5$.

- Guide for the Development and Management of Test Collections with Special Emphasis on Academic Settings (1985). Prepared by the ACRL Education and Behavioral Sciences Section's Ad Hoc Subcommittee on Test Collections. 69p. 6926-7. $\$ 12$; ACRL members $\$ 9$.

\section{Community and junior colleges}

- Guidelines for Two-Year College Learning
Resources Programs (1982). Reprinted from C\&RL News, January and February 1982. ACRL/AECT. 10p. Free.

- Statement on Quantitative Standards for Two-Year Learning Resources Programs (1979). 4p. Free.

\section{Conference Proceedings}

- Academic Libraries: Myths and Realities (1984). Proceedings of the Third National ACRL Conference, April 4-7, 1984, Seattle. 420p. 67876. \$28; ACRL members $\$ 20$.

- Energies for Transition (1986). Proceedings of the Fourth National ACRL Conference, April 9-12, 1986, Baltimore. Available in April. 6976-3. $\$ 30$; ACRL members $\$ 22$.

- Libraries and Accreditation in Institutions of Higher Education (1981). Proceedings of an invitational conference sponsored by ACRL and COPA. Edited by Julie A. C. Virgo. 176p. 6741-8. \$19; ACRL members $\$ 15$.

- New Horizons for Academic Libraries (1978). Sixty-six contributed papers from the First National ACRL Conference in Boston. Twelve microfiche. Free.

- Options for the 80's (1981). Fifty-six contributed papers from the Second National ACRL Conference in Minneapolis. Eleven microfiche. Free.

\section{Database searching}

- Online Bibliographic Database Searching in College Libraries: CLIP Note \#4-83 (1983). Compiled by David Carlson and P. Grady Morein. 132p. 6624-1. \$19; ACRL members \$15.

\section{Directories}

- Directory of Curriculum Materials Centers (1985). Compiled by Lois J. Lehman and Eva K. Kiewitt. 2nd ed. 194p. 6917-8. \$20; ACRL members $\$ 15$.

-Directory of Extension Library Services Personnel (1981). 7p. Free.

- Directory of Western European Specialists in North American Libraries (1984). 20p. 6762-0. \$5; ACRL members $\$ 3$.

- Slavic Ethnic Libraries, Museums and Archives in the United States: A Guide and Directory (1980). Compiled by Lubomyr R. Wynar. 164p. 6742-6. \$9; ACRL members $\$ 6$.

\section{Personnel issues and faculty status}

- Academic Status Survey (1981). Results of an ACRL 100 Libraries Project survey of academic status policies. 346p. 6737-X. \$17; ACRL members $\$ 12$.

- Governance in the Academic Library (1981). Betamax or 3/4U-matic videotape (specify) of six academic librarians reviewing issues relating to the status of the academic librarian and the ACRL 
Standard on Library Governance. \$35. (Rental only).

-Guidelines and Procedures for the Screening and Appointment of Academic Librarians (1977). Reprinted from C $b R L$ News, September 1977. 4p. Free.

- Job Descriptions: CLIP Note \#3-81 (1981). 255p. 6734-3. \$25; ACRL members $\$ 17.50$.

- Joint Statement on Faculty Status of College and University Librarians (1974). ACRL/AAUP/AAC. Reprinted from C $\triangleleft R L$ News, February 1974. 1p. Free.

- Management and Staff Development (1982). Proceedings of a workshop sponsored by the Northern California ACRL Chapter in 1979. 37p. 67353. $\$ 10$; ACRL members $\$ 8$.

- Model Statement of Criteria and Procedures for Appointment, Promotion in Academic Rank, and Tenure for College and University Librarians (1973). Reprinted from C $\downarrow R L$ News, September 1973 and October 1973, with a revision by the ACRL Board of Directors. 10p. Free.

- Performance Appraisal: CLIP Note \#1-80 (1980). 135p. 6733-7. \$10; ACRL members \$7.50.

- Standards for Faculty Status for College and University Librarians (1974). Reprinted from CむRL News, May 1974. 2p. Free.

- Statement on Collective Bargaining (1975) 1p. Free.

- Statement on the Terminal Professional Degree for Academic Librarians (1975). lp. Free.
- Travel Policies of Twenty-One College \& University Libraries (1980). 77p. 6736-1. \$3.

\section{Planning}

- Mission Statements for College Libraries: CLIP Note \#5 (1985). Compiled by Larry Hardesty, Jamie Hastreiter, and David Henderson. 190p. 6944-5. \$20. ACRL members $\$ 15$.

\section{Rare books, manuscripts and archives}

- Genre Terms: A Thesaurus for Use in Rare Book and Special Collections Cataloguing (1983). 41p. 6612-8. \$7.50; ACRL members \$5.50.

- Guidelines for the Security of Rare Book, Manuscript, and Other Special Collections (1983). Reprinted from C\&RL News, March 1982. 4p. Free.

- Guidelines on Manuscripts and Archives (1977). Compilation of policy statements prepared by the ACRL Rare Books and Manuscripts Section's Committee on Manuscripts Collections. Contains: Statement on Appraisal of Gifts; Statement on Legal Title; Statement on the Reproduction of Manuscripts and Archives for Noncommercial Purposes; Statement on the Reproduction of Manuscripts and Archives for Commercial Purposes; and Universal Gift Form and Instructions. 11 . Free.

- Joint Statement on Access to Original Research Materials (1979). This supersedes the 1976

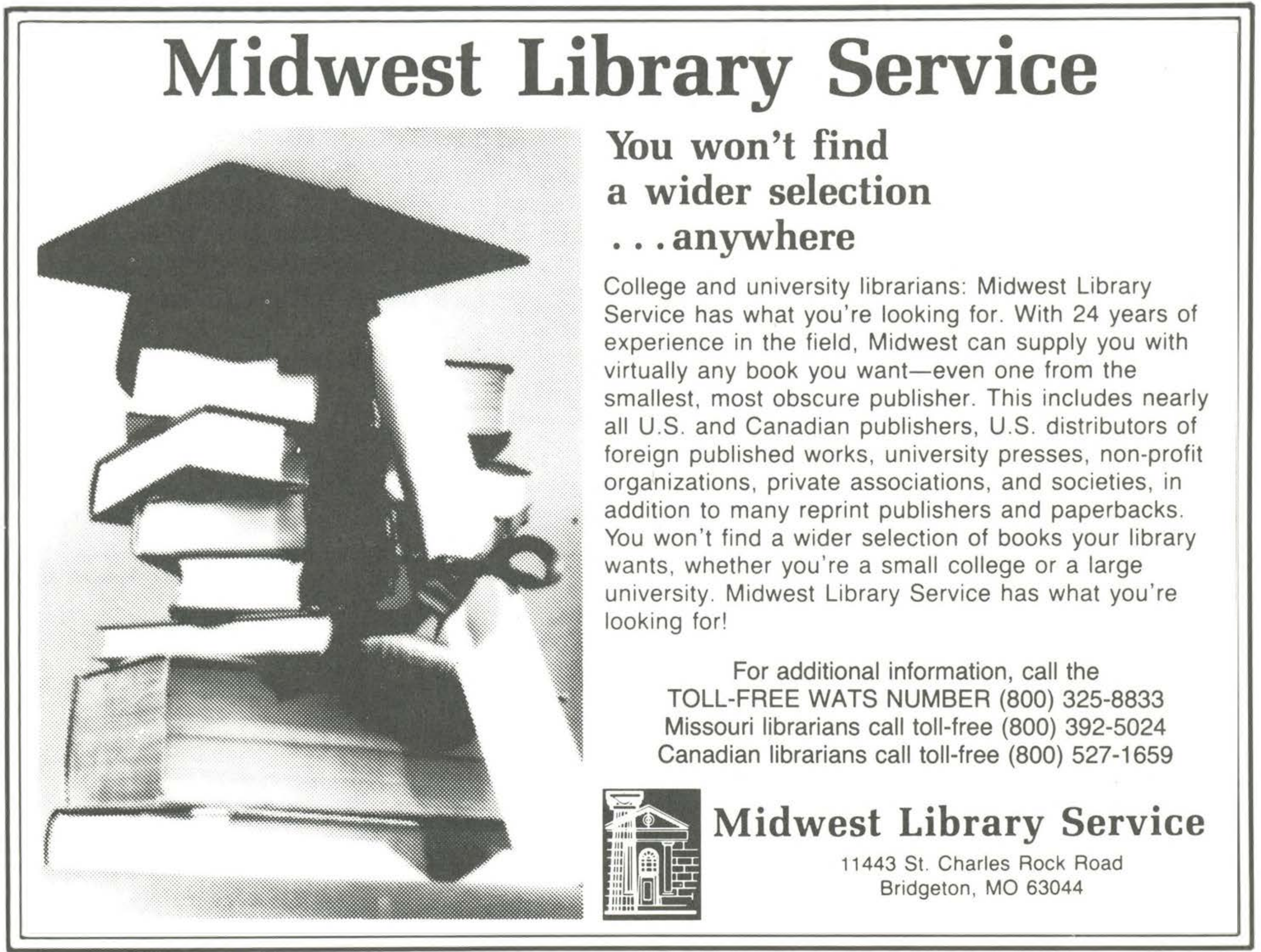


ACRL Statement on Access and the 1974 Standards for Access of SAA (American Archivist, January 1974). Reprinted from C\&RL News, April 1979. 2p. Free.

- Relator Terms for Rare Books, Manuscripts and Special Collections Cataloging (1981). Revised by the ACRL RBMS Standards Committee. Reprinted from CむRL News, October 1981. 4p. Free.

\section{Standards and guidelines-General}

- Other standards and guidelines are listed under more specific subject headings.

- Access Policy Guidelines (1975). Reprinted from C $\triangleleft R L$ News, November 1975. 2p. Free.

- College Library Standards: Questions and Answers (1974). Reprinted from C\&RL News, November 1974. 2p. Free.

- An Evaluative Checklist for Reviewing a College Library Program (1979). Based on the 1975 Standards for College Libraries. Reprinted from C $\nleftarrow R L$ News, November 1979. 12p. Free.

- Guidelines for Branch Libraries in Colleges and Universities (1975). Reprinted from C $b R L$ News, October 1975. 3p. Free.

-Guidelines for Extended Campus Library Services (1982). Reprinted from C\&RL News, March 1982. 2p. Free.

- The Mission of an Undergraduate Library (Model Statement). Reprinted from C\&RL News, November 1979. 5p. Free.

-Standards for University Libraries (1979). Reprinted from C\&RL News, April 1979. ACRL/ARL. 10p. Free.

- Standards for College Libraries (1986 edition). Draft version appeared in $C \triangleleft R L N e w s$, May 1985. A revised, final version will appear in a future issue of C\&RL News, after which free offprints will be available.

\section{Statistics}

- ACRL University Library Statistics 1983-84 (1985). Compiled by Sandy Whiteley. Statistics from 86 non-ARL university libraries in the U.S. and Canada. 55p. 6892-9. \$15; ACRL members $\$ 12$.

- ACRL University Library Statistics 1981-1982 (1983). Statistics from 92 non-ARL university libraries. 55p. 6596-2. \$15; ACRL members $\$ 12$.

- ACRL University Library Statistics 1978-1979 (1980). Statistics from 98 non-ARL university libraries. 47p. 6739-6. \$7.50; ACRL members $\$ 5$.

- Library Statistics of Colleges and Universities, 1982 Institutional Data (1984). Data from the 1981-82 HEGIS study conducted by the National Center for Education Statistics covering over 3000 academic libraries. 177p. 6640-3. \$16; ACRL members $\$ 12$.

•1984 "100 Libraries" Statistical Survey (1984).
Task Force on Academic Library Statistics. 92p. 6951-8. \$12; ACRL members $\$ 9$.

-Quantitative Criteria for Academic Research Libraries (1984). By Kendon L. Stubbs. 135p. 6788-4. \$19; ACRL members $\$ 15$.

\section{Periodicals}

- Choice. Book review journal of the Association of College \& Research Libraries. Eleven issues per year (July/August combined.) ISSN: 00094978. Editor/Publisher: Patricia Sabosik. Available by subscription only, $\$ 100 /$ year. Order from: Circulation Department, Choice, 100 Riverview Center, Middletown, CT 06457.

- Choice Reviews-on-Cards. Reviews from each monthly issue of Choice printed on $3 \times 5$ cards. Available to Choice subscribers only for $\$ 160 /$ year. Order from: Circulation Department, Choice, 100 Riverview Center, Middletown, CT 06457.

- College \& Research Libraries. Official journal of the Association of College and Research Libraries. Six bimonthly issues per year. Editor: Charles R. Martell Jr., California State University Library, Sacramento, CA 95819. Sent to ACRL members as a perquisite of membership. Also available on subscription, $\$ 35 /$ year. ISSN: 0010 0870. Order from: Subscription Department, American Library Association, 50 East Huron Street, Chicago, IL 60611.

- College \& Research Libraries News. Official news magazine of the Association of College and Research Libraries. Eleven issues per year (July/August combined). Editor: George M. Eberhart, ACRL/ALA, 50 East Huron Street, Chicago, IL 60611. Sent to ACRL members as a perquisite of membership. Also available on subscription, \$10/year. ISSN: 0099-0086. Order from: Subscription Department, American Library Association, 50 East Huron Street, Chicago, IL 60611.

- Fast Job Listing Service. A job listing which supplements in a speedy, timely fashion the classified advertising in C $b R L$ News. Published twelve times per year. Six-month subscription. $\$ 15$; ACRL members $\$ 10$. Order from: ACRL, $50 \mathrm{E}$. Huron St., Chicago, IL 60611.

- Index for Volumes 26 to 40 (1965-1979) of College \& Research Libraries and College \& Research Libraries News (1980). Prepared by Eldon W. Tamblyn. 6482-6. \$12; ACRL members $\$ 10$.

- Rare Books and Manuscripts Librarianship. Two issues per year. Available by subscription only. 0884-450x. $\$ 20$ U.S. and Canada; $\$ 25$ overseas.

\section{CE course syllabi}

ACRL continuing education course syllabi are available at a cost of $\$ 15$ (ACRL members $\$ 10)$ per syllabus. Order from ALA Order Department, 50 E. Huron St., Chicago, IL 60611.

- Librarians as Supervisors (CE 101) identifies the skills necessary to become an effective supervi- 


\section{Your invitation from EBSCO}

\section{THE MOST COMPLETE}

INTERNATIONAL DIRECTORY AND REFERENCE BOOK OF SERIALS EVER PUBLISHED:
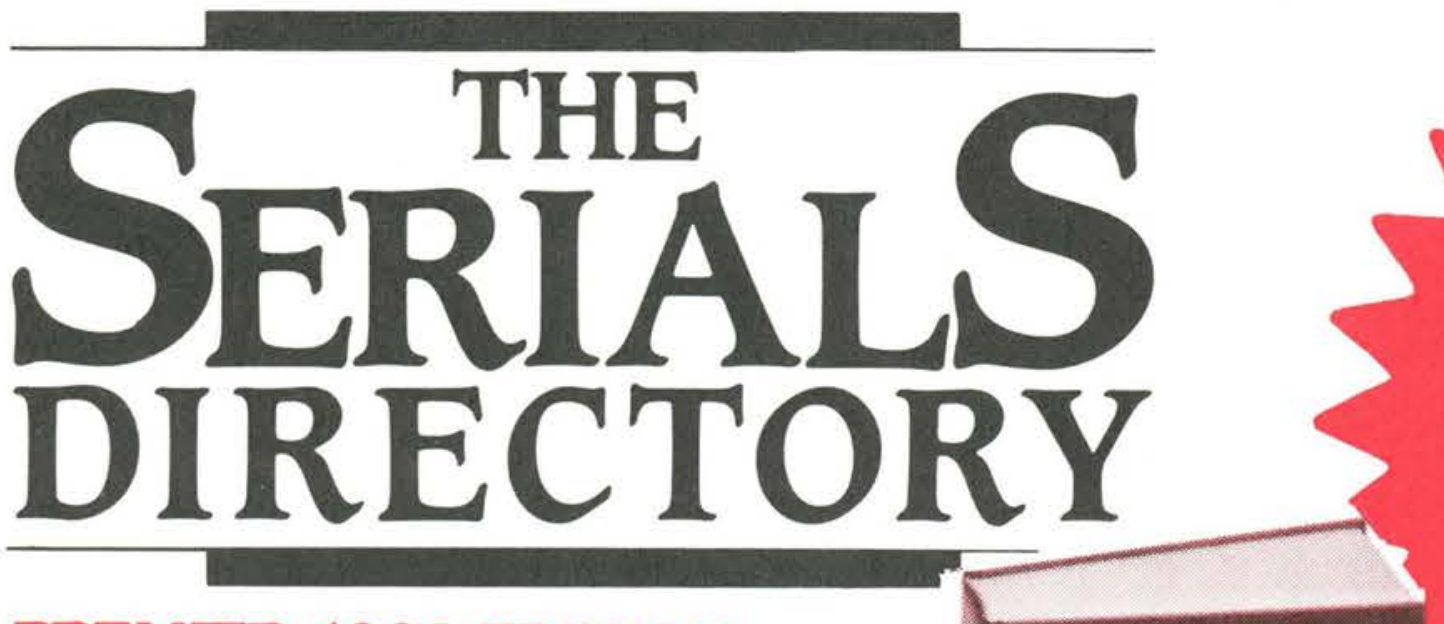

\section{PREMIER 1986 EDITION}

3 vols., more than 4000 pages

Publication price $\$ 249$

(+\$10 shipping/insurance/handling)

Special, until March 31, 1986:

\$224 (+\$10 shipping/

insurance/handling)

\section{YOU SAVE $\$ 25$}

- 113,000 serials-more than ANY other directory

- up to 37 separate pieces of data on each title

the ONLY directory with these major classifications; Library of Congress, Dewey Decimal, National Library of Medicine, and Universal Decimal Classifications, CODEN designations

longer serials descriptions than any other directory

the ONLY listing of over 2,000 ceased titles by both alpha and subject headings

complete listing of index and abstracts for each title

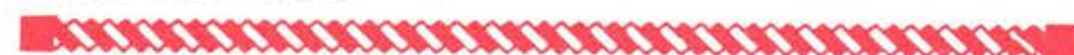

YOUR NO-RISK GUARANTEE

(Don't Pay for It Until You're Sure You Like It)

- EBSCO invites you to examine THE SERIALS DIRECTORY on your own premises, for one full month. You need not send payment now we'll bill you.

- If at any time during the first month you have it, you decide for any reason whatever not to keep it, return it undamaged. Your invoice for the special Charter Discount Price, $\$ 224+\$ 10$ shipping/in-

surance/handling, will be cancelled, no questions asked.

- This Unconditional Guarantee is backed by EBSCO, a dependable old-line company known to every library, publisher of the famous Librarian's Handbook.

Personally signed by:

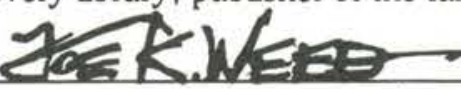

Joe K. Weed, Vice President

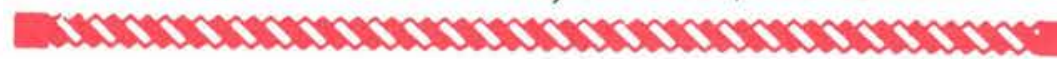

EBSCO PUBLISHING

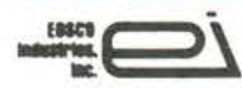

THE SERIALS DIRECTORY is published by EBSCO Publishing a Box 1943 a Birmingham, AL 35201 
sor within library organizations and explores current managerial concepts and practices through outlines, checklists and skill inventories. By Maureen Sullivan. 1982. 26p. 6745-0.

- Establishing the College BI Program: The Director's Role (CE 103) provides the academic library administrator with an overview of managerial considerations essential in establishing the successful BI program. By Dennis Robinson. 1981. 38p. 6746-9.

- Strategies and Tactics for Enhancing the Role and Position of the Library within the College or University (CE 104) (2nd edition) explores internal and external factors influencing the role of the academic library in the college and provides exercises designed to help library administration advance the library's position within the institution. By P. Grady Morein and H. Lea Wells. 1983. 6747-7.

- Time Management and Conducting Effective Meetings (CE 105) emphasizes time as a resource, describes the most frequent time problems encountered by librarians and discusses techniques for organizing and managing time. Also considers the meeting as a management tool: what meetings can and cannnot accomplish and how to use meetings successfully. By Sheila Creth. 1982. 53p. 6748-5.

-Performance Evaluation: A Goals-Based Approach (CE 106) introduces the concepts of performance evaluation based on performance goals and result-oriented evaluation. This includes explanation of different approaches and purposes for evaluation, review of the goals-based performance system, discussion of how to improve a poor evaluation system and discussion of evaluation as a developmental experience for both supervisor and employee. By Shelia Creth. 1984. 24p. 6754-X.

- Managing Student Workers in Academic Libraries (CE 107) describes the importance of student workers as a resource to the library and outlines strategies for better management of student workers through selection, training and supervision. By Michael D. Kathman and Jane M. Kathman. 1983. 45p. 6749-3.

- Interviewing Skills: Finding the Right Person for the Job (CE 109) reviews the legal guidelines affecting employment. Considers all aspects of conducting effective evaluative interviews including: preparation for the interview, question and listening techniques, reference checks and evaluating candidates against the requirements of the job/ needs of the organization. By Shelia Creth. 1984. 15p. 6875-9.

- Job Training: Developing Training Plans for Your Staff (CE 110) reviews learning principles and explains why initial orientation and training is critical to effective operation of library departments. Covers areas requiring training (for new employees, for performance improvement, in operational problems or changes and for employee development) and the responsibility of the supervisors in planning, conducting and evaluating training. By Anne G. Lipow. 1984. 64p. 6882-1.
- Principles of Strategic Planning in the Library Environment (CE 111) describes strategic planning as a process; introduces several strategic planning models including the "desired futures" model and applies models and processes to library planning. Material covered in syllabus is applicable to strategic planning for all types of libraries. By Julie A. C. Virgo. 1984. 30p. 6874-0.

- Improving Job Performance: Strategies for Supervisors (CE 112) discusses how librariansupervisors can create a climate for motivation, define job competencies, set performance standards, address performance problems and improve work effectiveness of their staffs. By Maureen Sullivan. 1985. 33p. 6810-0.

- An Introduction to Maps in Libraries: Maps as Information Tools (CE 201) describes the information potential of maps in the academic library environment. Considers acquisitions, collection development, reference, instruction space and equipment requirements. By David Cobb and Charles Seavey. 1982. 55p. 6750-7.

- Teaching How to Teach Science Reference Materials-A Workshop for Librarians Who Serve the Undergraduate (CE 205) examines the search strategies and reference tools that are particularly useful to undergraduate science majors. Syllabus gives equal emphasis to methods of teaching search strategies and use of reference tools. Attention is given to methods of learning how to use new science reference materials. 1 day course. By Martha White and Thomas G. Kirk. 97p. 1984. 6756-6.

- Creative Approaches to Video for Bibliographic Instruction (CE 206) examines uses of video, critical production issues and a financial comparison of various media products. By Thomas McNally. 1985. 30p. 6927-5.

- Writing the Journal Article and Getting it Published (CE 501) (2nd edition) reviews the publication process and considers effective strategies for publishing including selection of publishing medium, manuscript preparation and submission. By Richard D. Johnson. 1983. 39p. 6752-3.

- Survey Research Methods (CE 503) reviews the methodology of conducting survey research including sampling techniques, questionnaire design, data reduction and analysis and evaluation of surveys found in library literature. By Gary Golden. 1982.69p. 6753-1.

\section{ACRL Publications in Librarianship}

Editor: Arthur P. Young, Dean of Libraries, University of Rhode Island, Kingston, RI 02881.

Available on standing order or as single volumes. Order from ALA Publishing, 50 E. Huron St., Chicago, IL 60611.

Out-of-print titles are available from University Microfilms International, 300 N. Zeeb Road, Ann Arbor, MI 48106.

Titles in Print

-No. 39-Libraries for Teaching, Libraries for 
Research: Essays for a Century. Richard D. Johnson, comp. (1977). 276p. 0247-2. \$15.

-No. 40-Book Selling and Book Buying: Aspects of 19th Century British and North American Book Trades. Richard Landon, ed. (1979). 118p. 3224-X. \$15.

- No. 41-Women View Librarianship: Nine Perspectives. Kathryn Lundy, ed. (1980). 99p. 3251-7. $\$ 8$.

-No. 42-The Spirit of Inquiry in Library Sci- ence: The Graduate Library School at Chicago, 1921-1951. John Richardson. (1982). 238p. 32738. $\$ 35$.

-No. 43-The Landscape of Literatures: Use of Subject Collections in a University Library. Paul Metz. (1983). 157p. 3286-X. \$30.

-No. 44-The Carnegie Corporation and the Development of American College Libraries, 1928-1941. Neil A. Radford. (1984). 272p. 3295-9. $\$ 29.95$.

\section{Conference on Cooperative Preservation Programs}

On October 24-25, 1985, the representatives of thirteen non-profit cooperative preservation programs met in Andover, Massachusetts, to discuss the role of regional programs in an emerging national preservation strategy. The two-day, invitational Conference on Cooperative Preservation Programs for Libraries and Archives was hosted by the Northeast Document Conservation Center and funded by the National Endowment for the $\mathrm{Hu}$ manities. The purposes were to promote communication among these centers, plan for resource shar- ing, identify common needs, and articulate positions on national preservation issues.

As a result of discussions at the conference, the participants agreed that cooperation and coordination among the centers should include the following activities:

1) Joint development or sponsorship of workshops and other training programs.

2) Sharing of publications and teaching materials on a more systematic basis.

3) Development of a formal mechanism for shar-

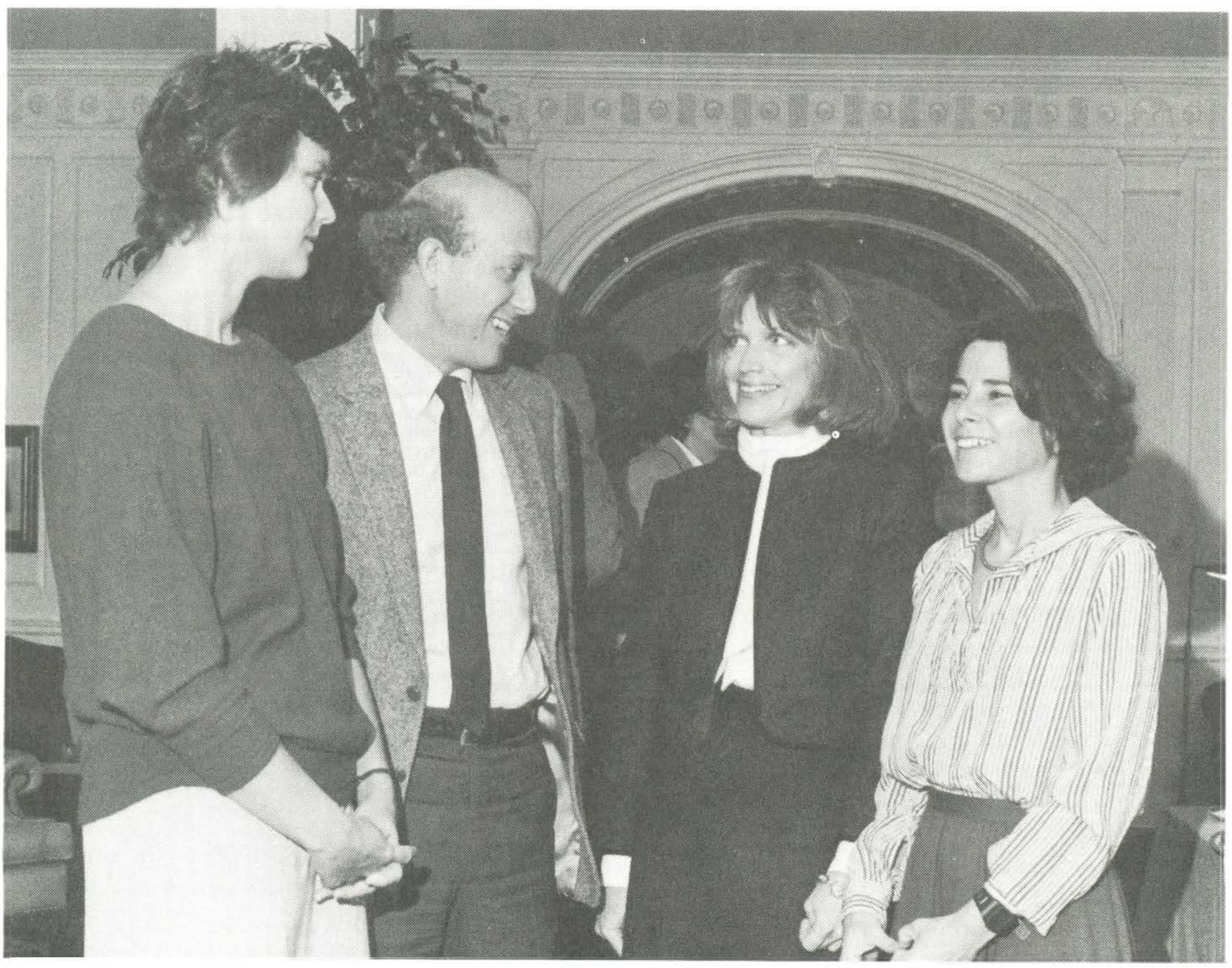

Participants at the Conference on Cooperative Preservation Programs: (left to right) Carolyn Morrow, LC National Preservation Program Office; Jeffrey Field, NEH Office of Preservation; Merrily Smith, LC National Preservation Program Office; Ann Russell, Northeast Document Conservation Center. 
ing information about the participants' activities.

4) Utilization of a centralized database to be developed by the Library of Congress.

While coordination of existing programs will contribute much to building an effective national preservation strategy, the participants identified a number of areas that still need to be addressed:

1) New cooperative programs must be established in areas where preservation needs cannot now be met locally.

2) Existing preservation education programs leading to a certificate and/or a degree must be supported and others need to be established.

3) Short-term training and education should continue and be expanded and additional, indepth training opportunities should be developed.

4) Research and development projects must be sponsored at appropriate scientific facilities to investigate and evaluate the application of science to preservation problems.

5) While research and development into information preservation technologies such as optical and video disk are ongoing, proven methods such as microfilming must receive continued support so that the content of endangered materials will be preserved.

6) The development and/or adoption of standards by national organizations such as ANSI provides a valuable service to the preservation profession and should continue.

7) Support and funding of the field services of regional preservation programs should continue.

8) Finally, participants agreed to continue their communications and information exchange on a regular basis as one way of promoting continued national cooperation and decided to meet again in December 1986.

The Conference provided an opportunity for professionals engaged in similar projects to meet each other and share common concerns. The participants concurred that the challenge posed by the deterioration of the nation's collections can be met more effectively as cooperative preservation programs are supported and expanded, and that nationwide coordination among regional preservation programs should be continued.

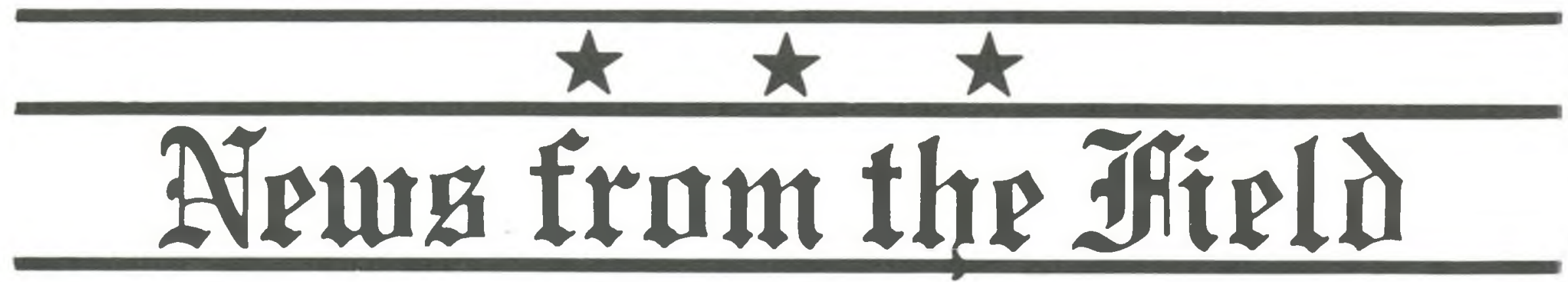

\section{Acquisitions}

- The Auburn University Libraries, Auburn, Alabama, have received several acquisitions of note.

The university library's Special Collections Department has added to its collection of Bibles with the acquisition of a 1541 Great Bible, a 1575 Bishops' Bible and a 1582 Rheims New Testament. The Great Bible, a revision of the 1535 Coverdale Bible, was commissioned by Thomas Cromwell because the 1535 Bible had been prepared mostly from Latin and Dutch translations without a complete comparison with Greek and Hebrew texts. Coverdale completed the first edition in 1539; the volume acquired by Auburn is thought to be from the fifth edition. The Bishops' Bible was completed in 1568, the work of "able bishops and other learned men," whose efforts were coordinated by Archbishop Matthew Parker. The volume acquired by Auburn appears to be from the sixth edition. The Catholic Rheims New Testament, sponsored by Cardinal William Allen and translated and annotated by Gregory Martin and others, was known at the time for its unabashedly controversial annotations. All three acquisitions are housed in the Treasure Room of Auburn's Ralph Brown Draughon Library.

Auburn's Library has also received a significant aerospace studies/aviation history collection. The collection, which was purchased from Hampton Books, Newberry, South Carolina, numbers between 5,000 and 6,000 items and is especially strong in materials for the study of the history of flight. While most of the collection is composed of monographs and serials, there are a number of technical reports and manuals, government agency documents, and other forms of printed material. Much of the collection is in English, but there is a significant amount of German language material. Other languages represented include French, Spanish, Italian, Russian, and several others.

- Harvard University's Andover-Harvard Theological Library, Cambridge, Massachusetts, has received a unique archive of tapes, slides, and periodicals relating to the influential Indian religious teacher Sri Anandamayi Ma (1896-1982). The archives were compiled by Gary Empie, a young American who lived in one of Sri Ma's ashrams for eight years, until his death in 1981. Sri Anandamayi Ma taught by answering questions put to her, and Empie gathered 139 cassette tapes of these questions and answers, as well as films, slides, and photographs of $\mathrm{Ma}$, and magazines and books relating to her life and work. The archives were presented to Harvard by Mr. and Mrs. Robert Empie and Markell Brooks. 